\title{
Valorization of territorial capital in function of rural tourism development - A case study of Kneževo municipality
}

\author{
Gordana Rokvić Knežić ${ }^{1 *}$, Milana Kalabić ${ }^{1}$, Željko Vaško ${ }^{1}$ \\ ${ }^{1}$ University of Banja Luka, Faculty of Agriculture, Banja Luka, Republic of Srpska, Bosnia \\ and Herzegovina
}

\begin{abstract}
The main goal of the research presented in the paper is to analyse the current state and level of development of rural area, in Kneževo municipality, as well as to define the possibilities of development of certain forms of rural tourism based on the territorial capital. In other words, the capital of space consists of natural and created capital. For the purposes of the valorisation of tourist potentials, the qualitative-quantitative methodology of the World Tourism Organization was used, which includes conducting a survey using standard forms of a questionnaire. Based on this survey, resource scoring was performed according to all external and internal factors, i.e. criteria. According to the results of the research, the indicator of tourist value for Kneževo municipality is estimated with 98.74 points out of a possible 400 points, or $25 \%$ of its potential tourist value.
\end{abstract}

Keywords: territorial capital, rural development, rural tourism, valorisation

JEL classification: Z, Z3, Z32

\section{Valorizacija teritorijalnog kapitala u funkciji razvoja ruralnog turizma - Studija slučaja opštine Kneževo}

Sažetak: Osnovni cilj rada je analiza postojećeg stanja i nivoa razvijenosti ruralnog područja opštine Kneževo, kao i definisanje mogućnosti razvoja određenih oblika ruralnog turizma na osnovu teritorijalnog kapitala. Teritorijalni kapital se sastoji od prirodnog i stvorenog kapitala. Za potrebe valorizacije turističkih potencijala korištena je kvalitativno-kvantitativna metodologija Svjetske turističke organizacije koja podrazumijeva provođenje ankete pomoću tipskih anketnih upitnika. Na osnovu tog istraživanja izvršeno je bodovanje resursa $\mathrm{i}$ to po svim eksternim i internim faktorima, odnosno kriterijumima. Prema rezultatima istraživanja pokazatelj turističke vrijednosti za opštinu Kneževo iznosi 98,74 od mogućih 400 bodova, odnosno $25 \%$ od potencijalne turističke vrijednosti.

Ključne reči: teritorijalni kapital, ruralni razvoj, ruralni turizam, valorizacija JEL klasifikacija: Z, Z3, Z32

\section{Introduction}

The connection between the structure and wealth of territorial capital and the structure of supply and development of tourism has been the subject of research by numerous authors. In

* gordana.rokvic@agro.unibl.org 
Rokvić Knežić, G. et al. - Valorization of territorial capital in function of rural tourism development - A case study of Kneževo municipality - Hotel and Tourism Management, 2020, Vol. 8, No. 2: 35-42.

their research, the territory is usually characterized by its various functions, its structure of rural economy, as well as their socio-cultural identity (Bogdanov \& Janković, 2013). Territorial capital refers to the complex of economic, cultural, social and environmental resources that ensures the development potential of a particular area. Territorial capital (spatial capital) is represented by a set of factors: from a geostrategic position, climate, size, human resources, transport and other infrastructure, all the way to cultural heritage. In other words, the territorial capital consists of natural and created capital. Natural capital is defined as the total capacity of the region and the total amount of natural resources including arable land, areas under forests, air, water, fisheries, protected areas, biodiversity and nonrenewable resources (oil, natural gas, coal, and forest). The capital created includes the capital of human resources and the capital created by human activity. The evaluation of economic, cultural, social and environmental resources in the form of qualitative and quantitative indicators, represents the valorisation of resources of a particular area so that it can be put in the function of the development. Tourist valorisation of rural areas is a precondition for the development of rural tourism. The main goal of the paper is to analyse the current state and level of development of the rural area on the case study of Kneževo municipality as well as to define the possibilities of developing certain forms of rural tourism based on the territorial capital that this municipality has.

In the introductory part, the theoretical setting of the problem of valorisation of territorial capital is explained and a link is given to the territorial capital of the municipality of Kneževo, and its tourist potentials. The results of the applied methodology for assessing the tourist value of internal and external factors, as well as the total tourist value of the destination are presented and discussed in the context of the case study of Kneževo municipality. In conclusion, the results of the research are summarized and recommendations are given for improving the tourist value of the destination.

\section{Background}

There are generally two groups of territorial capital dimensions in the literature: "hard" and "soft". The "hard" dimension or so-called "objective factors" can include: a geostrategic position, a size of the territory, agro climatic resources, economic structure and infrastructure, structure of labour force, degree of technological development, cultural heritage, human capital, as well as the quality of life and environment (Storper, 1997). The "soft" dimension, also called the "subjective", includes: the ability to understand processes, information, as well as the ability to implement joint development programs and plans, possession of capacity for innovation, social capital, the level of development of communication skills and connections between different actors, and subjective factors related to folk customs and traditions, local mentality, etc. (Storper, 1997). According to Bigaran et al. (2013), the components of territorial capital have three combined characteristics: real estate (not transferable), specificity (they have specific qualities and characteristics that are difficult to find elsewhere) and heritage property (they arise on the territory in a long period and it is not possible to create them in a short time).

Rural areas are no longer viewed only from the aspect of agricultural development, but as an area with potential for the development of new activities that often include tourism, recreational activities, production of indigenous products, as well as activities in the field of e-commerce (Saxena et al., 2007). In recent years, rural tourism has become the exit strategy of rural areas for the promotion of local resources, as well as the integration of local actors in development activities that ultimately lead not only to improving the competitiveness of the area, but also to income growth (Riveros \& Blanco, 2003). Although there are different definitions of the concept of rural tourism, some institutions have tried to define all the 
elements that this special type of tourism includes, whereby rural tourism is considered to include all tourist activities in rural areas, such as: hunting, fishing, winter, eco, health and cultural tourism (Baćac, 2011). The importance of rural tourism in rural areas is measurable by a number of indicators, as is its contribution to reducing depopulation and unemployment. Given the many industrial activities that have failed, tourism is emerging as an outstanding alternative strategy for rural development and as a complement to the agricultural activities of the local population. Likewise, rural tourism contributes to the renewal of the village, the protection of the environment and traditional architecture, and the protection of natural and cultural heritage.

The most significant contribution of tourism is reflected in the fact that only through the development of this activity certain properties of certain natural elements, phenomena and spaces can be valorised, and thus can be put in the function of meeting the appropriate needs. After the inventory of tourist resources, the tourist valorisation of space can be approached, which aims to evaluate, i.e. qualitative and quantitative assessment of tourist potential (space and facilities and phenomena in it), certain destinations from the aspect of assessing opportunities for tourist business. Two basic important categories in tourist valorisation are: attractiveness (usefulness and rarity) and value. Tourist value is a relative size, which depends on many factors related to demand in a given time and space, but also to subjective assessment of the tourist itself. The subjectivity of valorisation can lead to inadequate valorisation of tourism in the area being valued. Among the most important criteria of tourist value authors include: a geographical position of the area, the attractiveness of tourist product, traffic connections, the degree of development of tourist capacities, equipment of tourist canters, richness of cultural and historical heritage, etc. (Mojić, 2016).

This type of tourism in Republic of Srpska has begun to develop in recent times and has been given less attention compared to other types of tourism, which can be confirmed based on accommodation capacity, built tourist infrastructure, tourist attractions, development of tourist products and the number of entrepreneurs in rural areas. According to the Export Strategy for the Tourism Sector, the WTTC (World Travel \& Tourism Council) notes that "tourism demand in Southeast Europe (SEE) is on a steady pace and exports of tourism services in Bosnia and Herzegovina amounted to 1,136.6 million in 2011” (Rokvić et al., 2017, p. 159). The same organization further envisages "a nominal increase in the export of tourism services in Bosnia and Herzegovina of $8.3 \%$ per year, thus the total value of tourism services exports in 2021 would amount to BAM 2,025.4 million” (Rokvić et al., 2017, p. 159). According to the Ministry of trade and tourism of Republic of Srpska in the last twenty years, the growth rate of tourism has been twice the growth rate of gross domestic product (Ministry of Trade and Tourism of Republic of Srpska, 2011). The research of Berjan et al. (2014) points out that main difficulties in the development of rural tourism in Republic of Srpska including the lack of financial resources, high VAT and other taxes, a low occupation rate, as well as the "lack of qualified staff, lack of support from local authorities, complicated legal system and legislation, and outdated infrastructure and equipment” (p. 1808).

Republic of Srpska has a complex and in many ways specific geographical position, as well as a pronounced diversification of its tourism product. This confirms the fact that Republic of Srpska belongs to great natural regions: pannonia, mountain-valley and adriatic. Kneževo municipality is sitated in the central part of Republic of Srpska: area between pannonia region in north and adriatic region in south, belongs to mountain-valley area. Natural tourist values of this region are high and medium high mountains and deep river valleys, nature parks and reserves, specific flora and fauna, endemic and relict species, different forms of water, etc. which form the basis of various types of tourism (adventure, health, eco, excursion, hunting, fishing ...). The essence of the tourist product concerns valorization of a space such as mountains: Vlašić, Gole Planine, Ranče, Čemernica, Tisovac, Osmače, and 
Rokvić Knežić, G. et al. - Valorization of territorial capital in function of rural tourism development - A case study of Kneževo municipality - Hotel and Tourism Management, 2020, Vol. 8, No. 2: 35-42.

canyons of rivers: Cvrcke, Duboke, Ugra, Ilomska, as a space of integral tourist offers (Ministry of Trade and Tourism of Republic of Srpska, 2011). Currently, the residential tourism is the most represented type of tourism in Kneževo. This type of tourism usually includes visits of city population on weekends, holidays, vacations in their own or rented facilities (cottages).

\section{Materials and methods}

For the purposes of valorisation of tourist potentials, the qualitative-quantitative methodology of the World Tourism Organization was used (UNWTO, 2011), which includes conducting a survey using standard forms of questionnaire that can be useful to researchers during inventory and assessment. Based on these forms, scoring of resources (in the field) was performed according to all external and internal factors, i.e. criteria. In order to obtain the total value of the examined resource, first, all internal factors are added, then all external factors are added and finally the sum of internal multipliers with the sum of external factors (Mojić, 2016; Stanković, 2016).

All criteria, are classified into two large groups, internal and external valorization factors. Internal factors include specific qualities and values that each tourist resource has. There are, depending on their nature, two types of internal factors: those related to the degree of utilization of tourist resources (urbanization, infrastructure, equipment and tourist services) and those that refer to the inherent characteristics of a tourist resource and which essentially coincide with the characteristics of the resource itself that form the basis of its tourist value.

Internal factors, according to the methodology of the World Tourism Organization are represented with the following formula:

$$
(\mathrm{A}+\mathrm{B}+\mathrm{C}+\mathrm{D})=\mathrm{X}
$$

where: $\mathrm{X}=$ sum of partial estimates of internal resource factors, $\mathrm{A}=$ urbanization assessment, $\mathrm{B}=$ infrastructure assessment, $\mathrm{C}=$ assessment of equipment and services, $\mathrm{D}=$ assessment of inherent resource characteristics.

External factors are those that significantly affect or may significantly affect resourceoriented tourist flows and that determine their position in relation to the market and demand: possibility of access (accessibility), specificity of resources, proximity of emitting centres and importance of resources. According to the same methodology, external factors are calculated with the following formula:

$$
(E+F+G+H)=Y
$$

where: $\mathrm{Y}=$ sum of partial estimates of external resource factors, $\mathrm{E}=$ accessibility assessment, $F$ = resource specification assessment, $G$ = estimate of the proximity of emitting centres and $\mathrm{H}=$ assessment of resource significance.

After calculating the total value of internal and external factors, the total value of the tourist zone is obtained according to the formula:

$$
\mathrm{VZ}=(\Sigma \mathrm{FI} \times \Sigma \mathrm{FE})
$$

where: $\mathrm{VZ}=$ tourist value of the zone (region), $\mathrm{FI}=$ value of internal factors of the zone, as the sum of values of all internal factors of each resource (A, B, C, D) and $\mathrm{FE}=$ value of external factor (zone) regions. 
The value of external factors acts as an element of weighting of internal factors, so their mutual multiplication leads to the total value of the zone or region.

\section{Results and discussion}

Territorial capital - natural characteristics (relief, climate, hydrography, flora and fauna) available to Kneževo municipality, which represents the basic potential for the development of rural areas, was evaluated according to the following criteria: General properties; Specific properties - rarities; Attractiveness; Tourist significance; Competitiveness; Utilization. The results show that, although the municipality is rich in the natural territorial capital, which by its general and specific properties and attractiveness represents a great potential for tourism development, this potential is poorly or not used at all. The average competitiveness score was rated at 3 out of possible 5 , and the average utilization was rated at 2.28 points out of possible 5 (Figure 1).

Figure 1: The impact of territorial capital on the development of rural tourism in Kneževo municipality

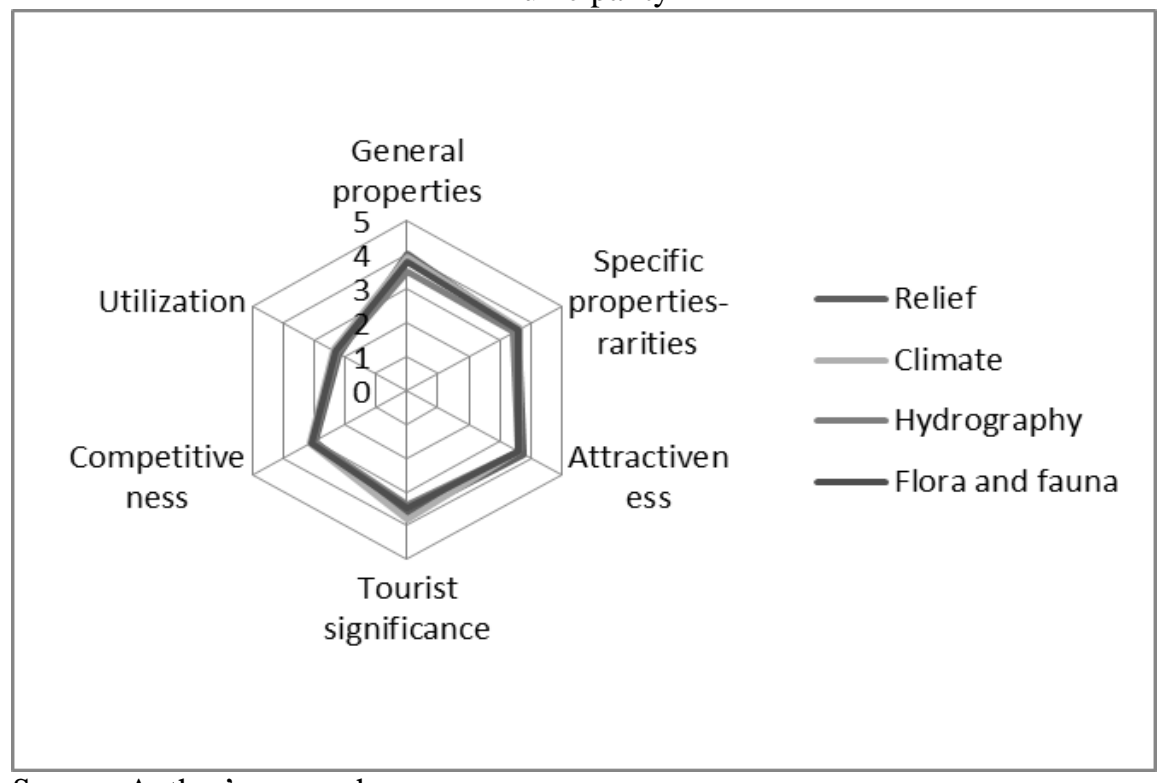

Source: Author's research

Among the internal factors of Kneževo municipality as a tourist destination, the highest average score was given to the inherent characteristics of the tourist resource (internal and immanent characteristics of the resource that form the basis of its tourist value), such as rural events, local customs and traditions, relief and climate, flora and fauna, hydrography, rural households, rural products, rural population. The lowest-rated factors are directly related to tourism as an activity, namely: tourist equipment and services, i.e. existing accommodation facilities, hotel and non-hotel accommodation, accommodation in rural households, restaurants, cafeterias, crafts, sports, travel agencies, as well as tourist services related to information for tourists, commercialization of tourist resources and activities, traffic connection with tourist attractions, etc. (Figure 2). 
Rokvić Knežić, G. et al. - Valorization of territorial capital in function of rural tourism development - A case study of Kneževo municipality - Hotel and Tourism Management, 2020, Vol. 8, No. 2: 35-42.

Figure 2: Influence of internal factors on the valorisation of territorial capital in Kneževo municipality

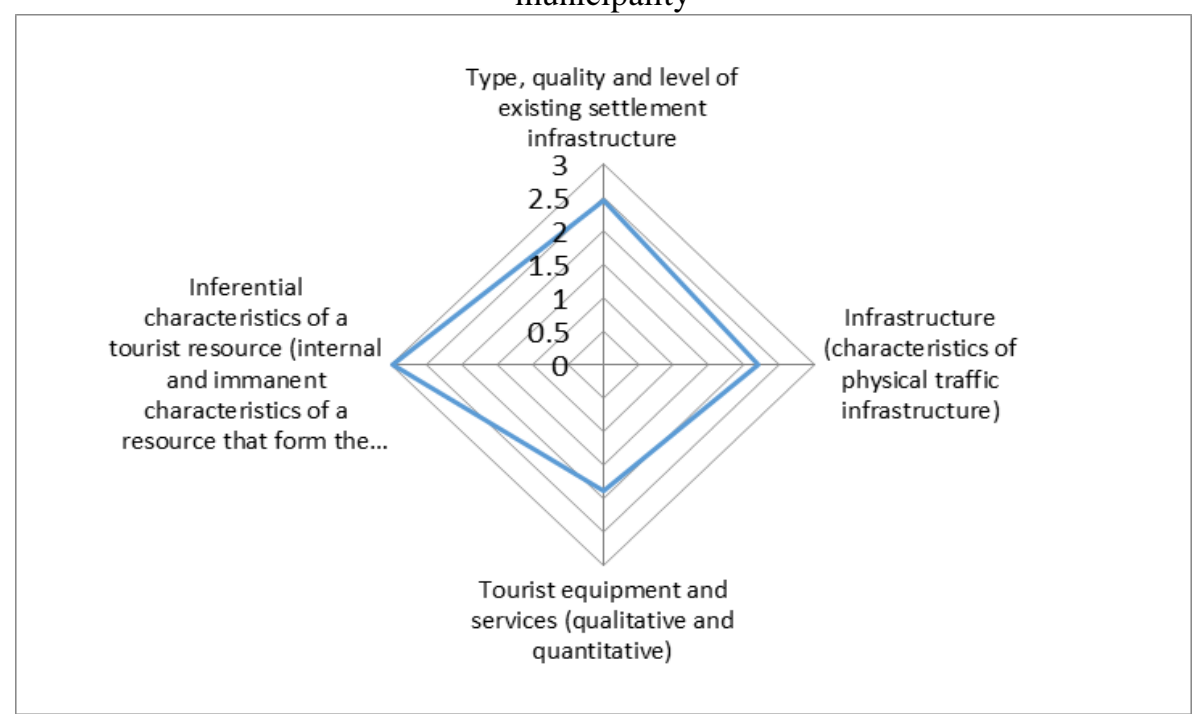

Source: Author's research

Among external factors, the highest rating was given to the assessment of infrastructure, in terms of the proximity of certain emitting centres for the demand for tourist services in Kneževo municipality, while the lowest rating was the factor of accessibility of tourist resources in municipality (Figure 3).

Figure 3: The influence of external factors on the valorisation of territorial capital in Kneževo municipality

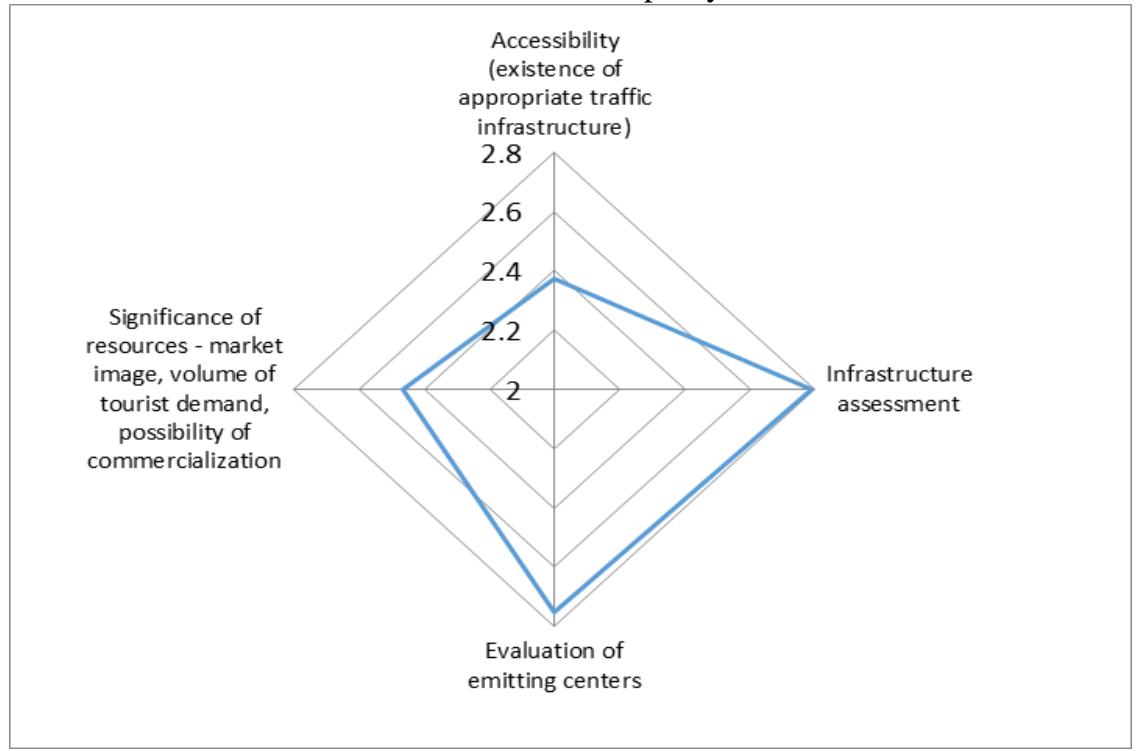

Source: Author's research

The results of the research show that there is a significant difference in the value of internal and external factors of territorial capital on the development of rural tourism in Kneževo 
municipality. According to respondents, Kneževo municipality realizes only about $50 \%$ of internal values ( 9.5 out of possible 20 points), as well as $50 \%$ of the value of external factors (average value of external factors 10.37 out of a possible 20 points), i.e. $25 \%$ of the value in relation to the maximum value of the tourist destination (98.74 out of a possible 400 points).

\section{Conclusion}

By analysing the territorial capital of Kneževo municipality, it can be concluded that the research area is rich in natural resources - conserved territorial capital, which is an excellent basis for the development of rural tourism. The results of the research show that there is a significant difference in the value of internal and external factors of territorial capital on the development of rural tourism in the municipality of Kneževo, where, according to respondents, Kneževo municipality realizes only about $50 \%$ of internal and external factors value. The lowest-rated factors are directly related to tourism as an activity, namely: tourist equipment and services, i.e. existing accommodation facilities: hotel and non-hotel accommodation, accommodation in rural households, restaurants, cafeterias, crafts, sports, travel agencies, as well as tourist services related to information for tourists, commercialization of tourist resources and activities, traffic connection with tourist attractions, etc. In order to use the territorial capital of Kneževo municipality, in the function of sustainable development of rural tourism, as the most efficient way to valorise the territorial capital of municipality, it is necessary to develop activities targeted in the direction of:

- $\quad$ establishment of a tourist organisation at a municipal level as well as partnership of local stakeholders with the purpose of strategic planning of tourism development, capacity building of service providers and tourism product development;

- development of tourist signalization in order to improve the accessibility of tourist attractions, and inclusion of potential tourist destinations on the map of roads of regional or international level (e.g. via Dinarica, bicycle routes, speleological tours, ski resorts, etc.);

- $\quad$ support for the development of rural tourism services on family farms, and support for the development of activities within rural tourism in municipality (organization of events, geographic identification and promotion of rural tourism products, gastronomic events, etc.);

- education of residents for the provision of services in rural tourism, e.g. accommodation, food, recreational and educational activities in the village, on the farm, etc.;

- better traffic connection of the village with the communities and the centre of the municipality;

- $\quad$ strengthening functional links between populated areas.

By improving the living conditions through the implementation of certain measures in rural areas, additional conditions would be created that would complete the entire territorial capital in the function of the development of rural tourism in Kneževo municipality.

At the end, it is worth noting that this research may contribute to the creation of analytical material in the field of rural tourism, as a basis for further valorization and activation of rural resources, primarily from the aspect of qualitative assessment. In the statistical records, rural tourism is classified in the group of "other types of tourism", so there are no quantitative data on the scope and level of development of this form of tourism in Republic of Srpska. The recommendation for future researchers is to develop a methodology for quantitative assessment of rural tourism contribution to overall tourism and rural development. 


\section{References}

1. Baćac, R. (2011). Priručnik za bavljenje seoskim turizmom: Od ideje do sopstvenog biznisa [Handbook for dealing with rural tourism: Step by step from idea to successful business]. Zagreb: Ministry of Tourism of the Republic of Croatia.

2. Berjan, S., Bilali, H., Radović, G., Sorajić, B., Driouech, N., \& Radosavac, A. (2014). Rural tourism in the Republic of Srpska: Political framework and institutional environment. Türk Tarım ve Doğa Bilimleri Dergisi [Turkish Journal of Agricultural and Natural Sciences], 1(2), 1805-1811. Retrieved September 15, 2020 from https://dergipark.org.tr/en/pub/turkjans/issue/13311/160984

3. Bigaran, F., Mazzola, A., \& Stefani, A. (2013). Enhancing territorial capital for developing mountain areas: The example of Trentino and its use of medicinal and aromatic plants. Acta Geographica Slovenica, 53(2), 379-391. https://doi.org/10.3986/AGS53403

4. Bogdanov, N., \& Janković, D. (2013). Territorial capital of rural areas: An example of analysis of potential for rural tourism development in Serbia. In D. Škorić, D. Tomić, and V. Popović (Eds.), Agri-food Sector in Serbia, State and Challenges (pp. 201-232). Belgrade, Serbia: Serbian Association of Agricultural Economists. https://doi.org/10.22004/ag.econ.157552

5. Ministry of Trade and Tourism of Republika Srpska (2011). Strategija razvoja turizma za period 2011-2020 godine [Tourism development strategy of Republic of Srpska for the period 2011-2020]. Banja Luka.

6. Mojić, J. (2016). Valorizacija ekonomsko geografskih resursa južne Srbije u funkciji turističkog razvoja [Valorisation of economic and geographical resources of southern Serbia in the function of tourist development]. Niš: University of Niš, Faculty of Economics.

7. Riveros, H., \& Blanco, M. (2003). El agroturismo, una alternativa para revalorizar la agroindustria rural como mecanismo de desarrollo local [The farmhouse, an alternative to revalue rural agroindustry as a mechanism for local development]. Lima, Peru: IICAProdar.

8. Rokvić, G., Galić, M., \& Vaško, Ž. (2017). Rural tourism as a means for strengthening rural economy. International Scientific Conference ITEMA 2017 Recent Advances in Information Technology, Tourism, Economics, Management and Agriculture (pp. 158167). Budapest, Hungary: Association of Economists and Managers of the Balkans.

9. Saxena, G., Clark, G., Oliver, T., \& Ilbery, B. (2007). Conceptualizing integrated rural tourism. Tourism Geographies, 347-370. http://dx.doi.org/10.1080/14616680701647527

10. Stanković, S. M. (2016). Theoretical foundations of tourist valorisation. Zbornik radovaGeografski fakultet Univerziteta u Beogradu, 64, 5-46. http://dx.doi.org/10.5937/zrgfub1664005S

11. Storper, M. (1997). The regional world: Territorial development in a global economy. New York, NY: Guilford Press.

12. UNWTO (2011). Policy and practice for global Tourism. Madrid: Spain. 